\title{
Dietary protein and carbohydrate requirement of juvenile Hawaiian limpet (Cellana sandwicensis Pease, 1861) fed practical diet
}

\author{
Nhan Thai Hua $(1) \cdot$ Harry Ako
}

Received: 26 April 2016/ Accepted: 28 September 2016/Published online: 11 October 2016

(C) The Author(s) 2016. This article is published with open access at Springerlink.com

\begin{abstract}
This study was conducted to evaluate dietary protein and carbohydrate requirement of juvenile Hawaiian limpets Cellana sandwincensis. A total of 64 juvenile limpets $(3.12 \pm 0.86 \mathrm{~g})$ were fed five different dietary protein levels ranging from 270 to $470 \mathrm{~g} \mathrm{~kg}^{-1}$ for 90 days. Carbohydrate and lipid levels were held constant at 180 and $49.7 \mathrm{~g} \mathrm{~kg}^{-1}$, respectively. Weight gain and growth rates of the animals did not differ significantly $(P>0.05)$ among the protein levels ranging from $270 \mathrm{~g} \mathrm{~kg}^{-1}\left(0.30 \%\right.$ day $\left.^{-1}\right)$ to $470 \mathrm{~g} \mathrm{~kg}^{-1}$ $\left(0.23 \% \mathrm{day}^{-1}\right)$. Next, opihi were fed four diets with protein levels from 210 to $500 \mathrm{~g} \mathrm{~kg}^{-1}$ with a constant carbohydrate level at $120 \mathrm{~g} \mathrm{~kg}^{-1}$. Weight gain and specific growth rates of opihi increased with increasing dietary protein from 210 to $350 \mathrm{~g} \mathrm{~kg}^{-1}$, and significantly $(P<0.05)$ decreased at the $500 \mathrm{~g} \mathrm{~kg}^{-1}$ diet. Highest weight gain, growth rates, and protein efficiency ratio were achieved at $350 \mathrm{~g} \mathrm{~kg}^{-1}$. Elevated carbohydrate levels $\left(180-370 \mathrm{~g} \mathrm{~kg}^{-1}\right)$ produced a significant difference $(P<0.05)$ in growth. The fastest growth rates of animals were obtained with $270 \mathrm{~g} \mathrm{~kg}^{-1}\left(0.27 \% \mathrm{day}^{-1}\right)$ and $320 \mathrm{~g} \mathrm{~kg}^{-1}\left(0.26 \% \mathrm{day}^{-1}\right)$. The weight gain of animals fed 180 and $370 \mathrm{~g} \mathrm{~kg}^{-1}$ carbohydrate diets were significantly $(P<0.05)$ lower than those of animals fed 270 and $320 \mathrm{~g} \mathrm{~kg}^{-1}$. We conclude that about $350 \mathrm{~g} \mathrm{~kg}^{-1}$ protein and $320 \mathrm{~g} \mathrm{~kg}^{-1}$ carbohydrate levels could be used for opihi.
\end{abstract}

Keywords Limpets · Opihi Cellana sandwicensis · Growth performance · Protein requirement · Carbohydrate requirement

\section{Introduction}

The Hawaiian limpet Cellana sandwicensis or yellow opihi is an economically important species with high potential for aquaculture in Hawaii. However, there are no practical aquaculture techniques for this species. Our previous study developed a feed which would sustain life and support a good growth rate for opihi (Hua and Ako 2012). We found that diet consisting of fishmeal, soybean meal, krill meal, and Porphyra was eaten at the highest rate and produced a good specific growth rate $\left(0.44 \%\right.$ day $\left.^{-1}\right)$.

Protein is a base component for muscle growth and sufficient quantity must be supplied to promote growth. No previous studies have been done on the protein requirements of opihi. Abalone was considered as reference

N. T. Hua $(\bowtie)$

College of Aquaculture and Fisheries, Cantho University, Can Tho, Viet Nam

e-mail: htnhan@ctu.edu.vn

H. Ako

Department of Molecular Biosciences and Bioengineering, University of Hawaii at Manoa, Honolulu, USA 
for opihi species because abalone is an herbivorous marine gastropod, so we are comfortable with a working hypothesis that opihi and abalone diets should have a degree of similarity. There have been many studies of dietary protein requirements for abalone. Various studies reported different dietary protein requirements for optimal growth of abalone species (Britz 1996; Gomez-Montes et al. 2003; Mai et al. 1995; Coote et al. 2000; Sales et al. 2003). The differences in quantitative dietary protein level among different studies may have been due to the mismatch of the amino acid profiles of the diets with the amino acid profiles of the animal tissue.

Dietary carbohydrate could act as good energy sources for abalone H. kamtschatkana (Taylor 1997), sparing the amount of protein needed. Providing an adequate amount of lipid or carbohydrate in the diet would minimize the use of expensive protein (National Research National (NRC) 1993). Many studies have used lipid as an energy source and the optimal dietary protein to lipid ratio levels have been studied in fish (Satpathy et al. 2003; Alam et al. 2003), and abalone (Britz and Hecht 1997). For limpets, studies have showed that amylase activity was very high in the digestive system of the patellacean limpets including Patella vulgate, Cellana radiata, and Collisella pelta (Branch 1981). On the other hand, lipase activity has not been found in limpets, and studies have shown that lipases are very low in the digestive gland of abalone (Knauer et al. 1996; Fleming et al. 1996). Thongrod et al. (2003) used modified starch and fish oil to determine the optimum ratio of carbohydrate versus lipid levels for the growth of tropical abalone $H$. asinia. They found that the growth performance of abalone was relatively good when they were fed a diet containing a higher proportion of carbohydrate, up to $470 \mathrm{~g} \mathrm{~kg}^{-1}$, whereas higher lipid levels $\left(>58.0 \mathrm{~g} \mathrm{~kg}^{-1}\right)$ did not help abalone growth. The literature suggests that there is certainty in where abalones obtain their energy from. Study by Brizt confirmed that adjusting lipids did not affect growth rate. Carbohydrates are inexpensive and could minimize the cost of opihi feed. Thus, carbohydrate was considered as the second nutrient after dietary protein to be worth pursuing for opihi.

In the present study, the growth performance of opihi was examined using a practical diet at varying protein and carbohydrate levels using the best performance diet including of fishmeal, soy meal, krill meal, and Porphyra.

\section{Materials and methods}

Experimental diets

Formulations of dietary protein and carbohydrate levels are shown in Table 1. Two protein feeding trials were conducted. For the preliminary protein trial, five different dietary protein levels of 270, 320, 370, 420, and $470 \mathrm{~g} \mathrm{~kg}^{-1}$ were tested for 90 days. A package of protein ingredients of fish meal, defatted soybean, and krill meal, including Porphyra was used as a base diet because these ingredients were found to have the best performance in both palatability and supporting good growth of opihi (Hua and Ako 2012). Wheat flour was used as starch and diatomacetous earth was used as filler in the diets as protein weight was decreased. Based on the results of this trial and due to unexpected issue of low survival rate due to removal for weighing, the second protein feeding trial was repeated with four different formulated dietary protein levels consisting of $210,300,350$, and $500 \mathrm{~g} \mathrm{~kg}^{-1}$.

For carbohydrate trial, a constant protein level of $270 \mathrm{~g} \mathrm{~kg}^{-1}$ protein with low lipid level of $35.0 \mathrm{~g} \mathrm{~kg}^{-1}$ was employed. Four different dietary carbohydrate levels of $180,270,320$, and $370 \mathrm{~g} \mathrm{~kg}^{-1}$ were formulated and tested for 90 days. Wheat flour was used as carbohydrate source and diatomacetous earth was used to fill out in the diets as the carbohydrate level was decreased. Protocols for diet preparation in this study were done as described in the previous study (Hua and Ako 2012).

Experimental animals

Animals $(3.12 \pm 0.86 \mathrm{~g})$ used for this study were collected from remote shoreline areas in Oahu Island, Hawaii, USA. After collection, the animals were immediately transferred to the laboratory and placed in aquaria with plastic liners, with algae seeded with benthic diatoms from Hawaii Institute of Marine Biology. An aquarium biofilter system $\left(586 \mathrm{~L} \mathrm{~h}^{-1}\right)$ was used to simulate water movement. They were held for about 3 days of acclimation. Thereafter, nine opihi were selected for each experimental group and their initial 


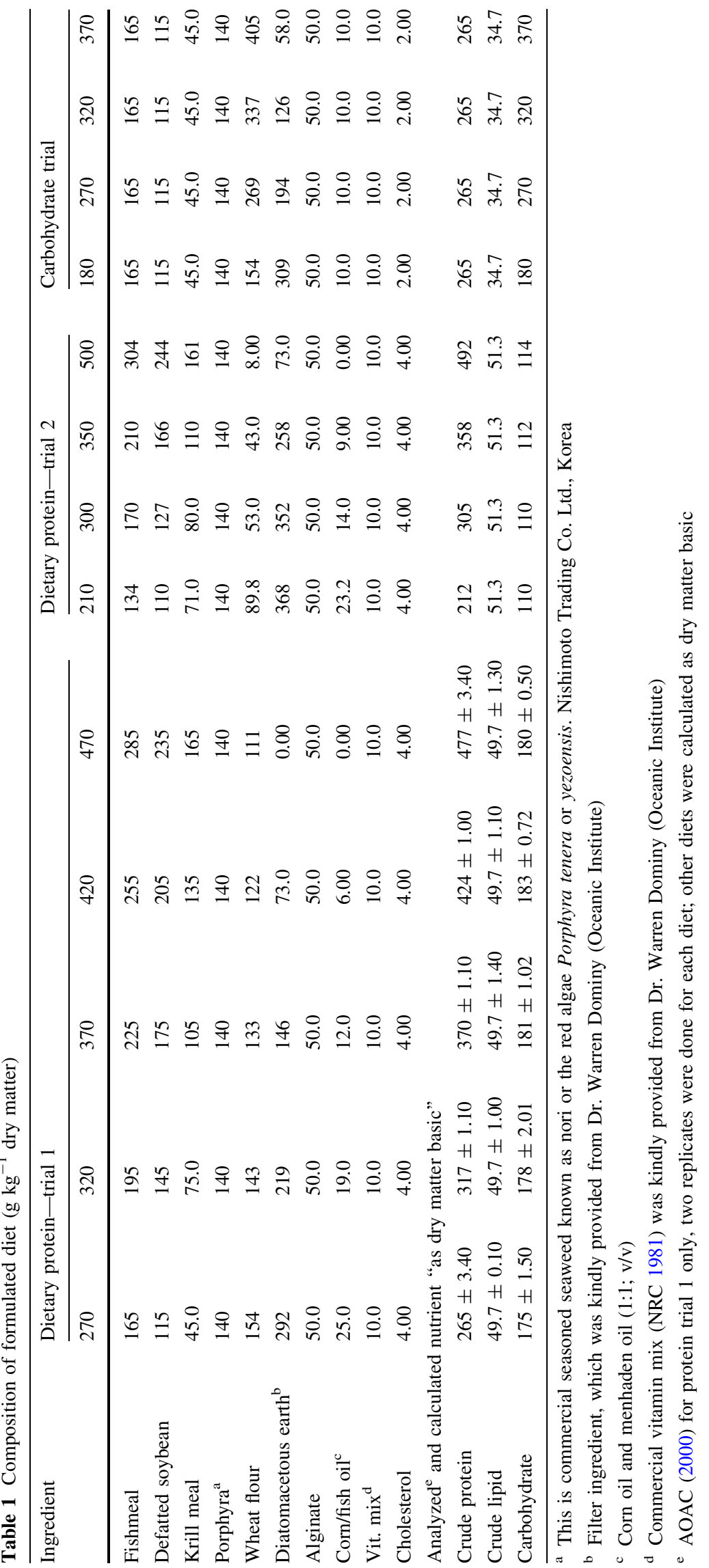



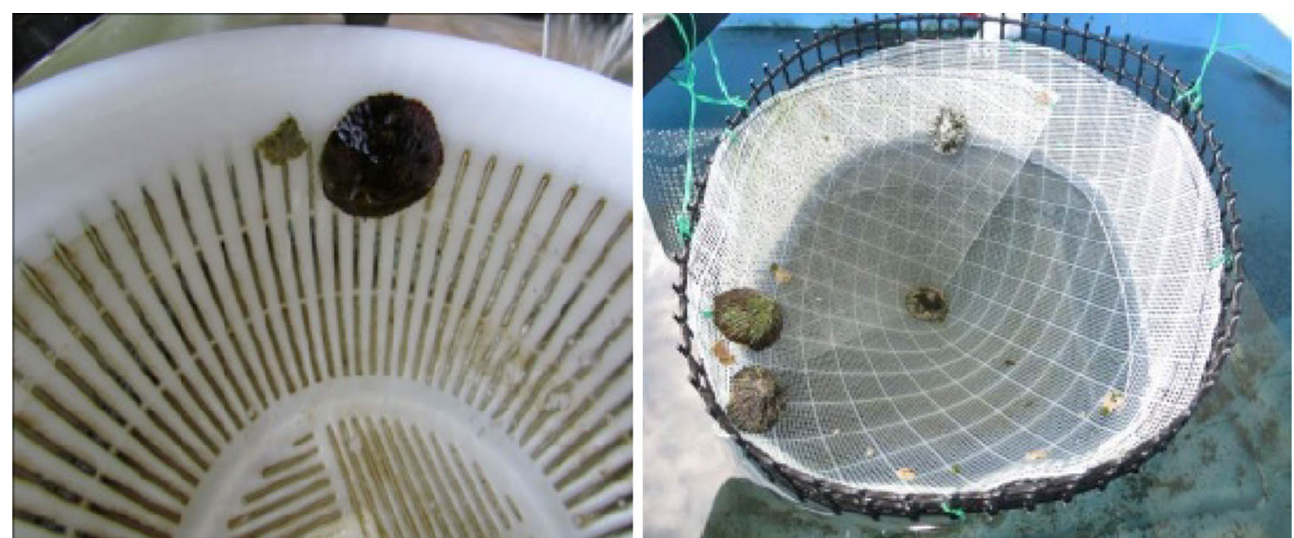

Fig. 1 Representative plastic colander (left) using for protein trial 1 and colander with a layer of plastic tubs (right) using for protein trial 2 and others

weight and shell length were measured. For the preliminary trial, each individual was placed into its own plastic colander ( $20 \mathrm{~cm}$ diameter). The colanders were put in tubs, nine colanders per tub. Animals that died in the first 3 days after placement into the test system were replaced. We observed a few more mortalities due to removing the animals from the colanders for weighing. Therefore, softer containers made of soft screen polyethylene plastic, cone shaped, $13 \mathrm{~cm}$ diameter, $17 \mathrm{~cm}$ height, were used in the second protein trial (Fig. 1). The experiment was done in recirculating system at a flow rate of $3 \mathrm{~L} \mathrm{~min}^{-1}$. Water temperature ranged from 24 to $26{ }^{\circ} \mathrm{C}$ and salinity was maintained at $35 \mathrm{mg} \mathrm{L}^{-1}$.

Feeding regime and feeding evaluation were as in our previous description (Hua and Ako 2012). The animals were fed one time per day at feeding rate about $0.73 \pm 0.53 \%$, at 18:00 daily, as animals did not eat during the day. It was noticed that the animals normally did not eat well for the first few days after putting them into the test system, therefore feeding rate of animals for 3 days after stocking and 3 days after replacement were not counted in our calculations. With this taken into consideration, as animals were conditioned to the artificial feed used in the feed trials, the following data were calculated:

Feed consumption (\% dry matter/soft body weight/day) for individual

$$
=[\text { feed eaten }(\mathrm{g} \text {, dry weight }) / \text { soft body weight }(\mathrm{g})] \times 100
$$

Protein intake $=$ total feed intake $(\mathrm{g} /$ individual $) \times(\mathrm{g}$ protein $/ \mathrm{g}$ dry feed $)$

Sampling and analytical methods

The growth of animals in weight $(\mathrm{g})$ and shell length $(\mathrm{cm})$ was measured monthly. The growth was expressed in terms of specific growth rate (SGR), weight gain, and shell length increase. The shell length was measured with an electronic digital caliper $(0.01 \mathrm{~mm})$ and weight determined with an electronic scale $(0.01 \mathrm{~g}$ error $)$ every 4 weeks

$$
\begin{gathered}
\text { Mean weight gain }(\mathrm{g} / \text { individual })=\mathrm{Wf}-\mathrm{Wi} \\
\text { Weight gain }(\mathrm{WG}, \%)=[\{\mathrm{Wf}(\mathrm{g})-\mathrm{Wi}(\mathrm{g})\} / \mathrm{Wi}(\mathrm{g})] \times 100 \\
\text { Specific growth rate }(\mathrm{SGR})=\{(\operatorname{lnWf}-\ln \mathrm{Wi}) / T\} \times 100,
\end{gathered}
$$

where Wf is final weight, Wi is initial weight, and $T$ is total day of the experiment.

Feed conversion ratio $(\mathrm{FCR})=$ total feed eaten $(\mathrm{g}) /$ wet weight gain $(\mathrm{g})$. 
Table 2 The A/E ratio [(each EAA/total EAA $) \times 1000$ ] amino acids of the dietary protein and opihi tissue

\begin{tabular}{|c|c|c|c|c|c|c|c|c|c|c|}
\hline \multirow[t]{2}{*}{ Essential AA } & \multicolumn{6}{|c|}{ Preliminary protein trial } & \multicolumn{4}{|c|}{ 2nd protein trial } \\
\hline & Opihi tissue & 270 & 320 & 370 & 420 & 470 & 210 & 300 & 350 & 500 \\
\hline Arg & 224 & 123 & 118 & 129 & 125 & 139 & 208 & 198 & 190 & 173 \\
\hline His & 33.8 & 39.5 & 37.4 & 41.5 & 39.9 & 44.6 & 29.1 & 29.4 & 29.8 & 32.3 \\
\hline Ile & 81.4 & 88.7 & 89.5 & 87.7 & 88.6 & 99.5 & 80.4 & 80.9 & 81.2 & 80.8 \\
\hline Leu & 146 & 158 & 157 & 155 & 156 & 177 & 149 & 148 & 147 & 142 \\
\hline Lys & 69.2 & 159 & 170 & 149 & 160 & 178 & 110 & 112 & 114 & 116 \\
\hline Met/Cys & 68.3 & 74.1 & 75.1 & 77.6 & 77.7 & 87.0 & 51.2 & 53.5 & 55.4 & 57.4 \\
\hline Phe/Tyr & 123 & 158 & 161 & 159 & 160 & 179 & 187 & 194 & 200 & 219 \\
\hline Thr & 136 & 97.9 & 92.0 & 97.8 & 93.4 & 98.0 & 78.9 & 79.1 & 79.3 & 78.4 \\
\hline Val & 117 & 103 & 99.9 & 103 & 99.8 & 111 & 107 & 105 & 104 & 100 \\
\hline
\end{tabular}

Protein efficiency ratio $=$ Wet weight gain $(\mathrm{g}) /$ protein intake $(\mathrm{g})$.

All diets of protein trial 1 were subjected to proximate analysis (AOAC 2000) at the Aquatic Feed and Nutrition Laboratory, Oceanic Institute, Hawaii, USA. Two replicates were done for each diet.

Because of our hypothesis that previous studies had showed wide spreads in optimal protein levels due to inappropriate amino acid balance for abalone; the amino acid profiles of opihi tissue were determined to have an optimal balance in our trials. The amino acid profiles of opihi tissue and of the dietary protein in trial 1 were determined by Dr. Ju at the Aquatic Feed and Nutrition Laboratory, Oceanic Institute, Hawaii, USA, according to the described method of Ju et al. (2008). The results are presented as A/E ratio (Table 2). Most of the essential amino acids of diets were identical and/or close to the amino acid profile of opihi tissue except for Arg and Thr which were lower in the experimental diets compared to tissue.

Solid leaching of diets

Weight matter leaching was examined for the second dietary protein trial. The experiment was conducted in an experimental test system. Three pieces of each feed $\left(1.0 \mathrm{~cm}^{2} /\right.$ piece $)$ served as for replication, three replications per diet. They were weighed to obtain the initial weights of the three replications, then placed in an empty colander without opihi for $12 \mathrm{~h}$. Stability of feed was assessed according to the equation: Water absorbed $(\%)=\{(\mathrm{FW}-\mathrm{IW}) / \mathrm{IW}\} \times 100$. Where IW is initial weight of feed, and FW is the final weight of feed of the same diet after being immersed in water. The retained feed was rinsed with fresh water and transferred to a drying oven for $12 \mathrm{~h}$ at $100{ }^{\circ} \mathrm{C}$ to obtain dry weight. To obtain the initial dry weight of each diet, three other pieces of each diet were weighed and dried in the oven, this dry weight served as initial dried weight control. This data were used to determine leaching losses due to soaking.

Data analysis

Collected data were subjected to one-way ANOVA, followed by Tukey test to compare the weight gain (g), specific growth rate ( $\%$ body weight/day), feed consumption rate ( $\%$ dry matter/body weight/day), and feed conversion ratio (dry feed eaten/weight gain) using SPSS (version 11.5; SPSS Inc., Chicago. IL, USA). The data on weight gain (\%) were subjected to the quadratic regression analysis model (Mai et al. 1995; Sales et al. 2003) and the optimal protein requirement of opihi was estimated. 
Table 3 Effect of dietary protein on growth performance, specific growth rate (SGR), feed consumption, protein efficiency ratio (PER), and survival of opihi C. sandwicensis

\begin{tabular}{|c|c|c|c|c|c|c|}
\hline $\begin{array}{l}\text { Dietary protein } \\
\left(\mathrm{g} \mathrm{kg}^{-1}\right)\end{array}$ & $\begin{array}{l}\text { Initial weight } \\
\left(\mathrm{g} \mathrm{opihi}^{-1}\right)\end{array}$ & $\begin{array}{l}\text { Weight gain } \\
\left(\text { g opihi }^{-1}\right)\end{array}$ & $\begin{array}{l}\text { SGR } \\
\left(\% \text { day }^{-1}\right)\end{array}$ & $\begin{array}{l}\text { Feed consumption } \\
\text { (\% DM/BW/day) }\end{array}$ & PER & $\begin{array}{l}\text { Survival } \\
(\%)\end{array}$ \\
\hline \multicolumn{7}{|l|}{ Pre. trial } \\
\hline 270 & $3.35 \pm 0.79^{\mathrm{a}}$ & $1.02 \pm 0.30^{\mathrm{a}}$ & $0.30 \pm 0.12^{\mathrm{a}}$ & $0.90 \pm 0.14^{\mathrm{a}}$ & $4.29 \pm 1.03^{\mathrm{a}}$ & 67 \\
\hline 320 & $2.72 \pm 0.54^{\mathrm{a}}$ & $1.01 \pm 0.30^{\mathrm{a}}$ & $0.35 \pm 0.11^{\mathrm{a}}$ & $0.91 \pm 0.16^{\mathrm{a}}$ & $4.54 \pm 1.45^{\mathrm{a}}$ & 75 \\
\hline 370 & $2.65 \pm 1.01^{\mathrm{a}}$ & $0.97 \pm 0.31^{\mathrm{a}}$ & $0.41 \pm 0.10^{\mathrm{a}}$ & $1.05 \pm 0.13^{\mathrm{a}}$ & $4.23 \pm 1.52^{\mathrm{a}}$ & 50 \\
\hline 420 & $2.43 \pm 0.48^{\mathrm{a}}$ & $0.83 \pm 0.38^{\mathrm{a}}$ & $0.32 \pm 0.10^{\mathrm{a}}$ & $0.81 \pm 0.08^{\mathrm{a}, \mathrm{b}}$ & $4.26 \pm 1.03^{\mathrm{a}}$ & 63 \\
\hline 470 & $2.44 \pm 0.51^{\mathrm{a}}$ & $0.54 \pm 0.25^{\mathrm{a}}$ & $0.23 \pm 0.07^{\mathrm{a}}$ & $0.56 \pm 0.12^{\mathrm{b}}$ & $3.95 \pm 0.45^{\mathrm{a}}$ & 56 \\
\hline \multicolumn{7}{|l|}{ Trial 2} \\
\hline 210 & $5.00 \pm 1.59^{\mathrm{a}}$ & $0.56 \pm 0.26^{\mathrm{a}, \mathrm{b}}$ & $0.19 \pm 0.09^{\mathrm{a}, \mathrm{b}}$ & $0.46 \pm 0.20^{\mathrm{a}}$ & $5.70 \pm 2.72^{\mathrm{ab}}$ & 89 \\
\hline 300 & $5.93 \pm 2.09^{\mathrm{a}}$ & $0.77 \pm 0.40^{\mathrm{a}, \mathrm{b}}$ & $0.22 \pm 0.13^{\mathrm{ab}}$ & $0.41 \pm 0.16^{\mathrm{a}}$ & $6.20 \pm 3.78^{\mathrm{a}}$ & 100 \\
\hline 350 & $5.56 \pm 2.58^{\mathrm{a}}$ & $1.00 \pm 0.44^{\mathrm{a}}$ & $0.28 \pm 0.12^{\mathrm{a}}$ & $0.40 \pm 0.17^{\mathrm{a}}$ & $6.79 \pm 1.41^{\mathrm{a}}$ & 89 \\
\hline 500 & $5.17 \pm 0.98^{\mathrm{a}}$ & $0.38 \pm 0.10^{\mathrm{b}}$ & $0.13 \pm 0.04^{\mathrm{b}}$ & $0.28 \pm 0.13^{\mathrm{b}}$ & $2.47 \pm 0.75^{\mathrm{b}}$ & 89 \\
\hline
\end{tabular}

a,b Means, within the column, different superscript letters are significant differently $(P<0.05)$ in the same trial

\section{Results}

Survival

A low survival rate in the first protein trial could affect the strength of results. Mortality (25-50\%) was due in part to handling during weighing when the animals were removed from the colander, and was not affected by dietary protein. They died after weighing, we assume, due to physical injury and/or stress. A higher survival rate was obtained in the second protein trial using the softer containers, ranging from 89 to $100 \%$.

Growth

Growth performance of opihi fed with different dietary protein levels is shown in Table 3. For the first protein trial, statistical analysis by One-way ANOVA followed by Tukey-Kramer showed that there was no significant $(P>0.05)$ effect of various protein levels $\left(270-470 \mathrm{~g} \mathrm{~kg}^{-1}\right)$ on the weight gain and the specific growth rates of animals, although this dropped off insignificantly at higher protein levels from 420 to $470 \mathrm{~g} \mathrm{~kg}^{-1}$.

There was a significant $(P<0.05)$ difference in weight gain and specific growth rates of animals in the second dietary protein trial over 60 days; possibly due to better methods and more practice. Weight gaintracked specific growth rates were progressively increased to maximum at $350 \mathrm{~g} \mathrm{~kg}^{-1}$ protein diet, and significantly higher than those animals fed with $500 \mathrm{~g} \mathrm{~kg}^{-1}$, but did not differ significantly compared to the 210 and $300 \mathrm{~g} \mathrm{~kg}^{-1}$ diets.

The growth response of opihi in terms of weight gain (\%) of animals in dietary protein trial 2 was fitted into quadratic models (Fig. 2). The best fit for the estimation of optimal protein level could be described as $Y=-0.0003 x^{2}+0.234 x-21.8\left(R^{2}=0.96\right)$. The trend of growth showed that maximum weight gain appeared to be about $350 \mathrm{~g} \mathrm{~kg}^{-1}$ dietary protein.

There was a significant difference in feed consumption of animals. Feed consumption for animals that were fed with $500 \mathrm{~g} \mathrm{~kg}^{-1}$ dietary protein was significantly lower $(P<0.05)$ than those animals that were fed with dietary protein of 210,300 , and $350 \mathrm{~g} \mathrm{~kg}^{-1}$ in the second protein trial. The highest feed efficiency ratio tracked the weight gain of those animals that were fed with the $350 \mathrm{~g} \mathrm{~kg}^{-1}$ dietary protein and was significantly higher than $500 \mathrm{~g} \mathrm{~kg}^{-1}$ diet.

The percentage of solids remaining among the diets was $98.0 \pm 1.13,96.8 \pm 1.39,97.8 \pm 1.170$, and $98.5 \pm 0.32 \%$ for $210,300,350$, and $500 \mathrm{~g} \mathrm{~kg}^{-1}$ of dietary protein, respectively. Statistical analysis for solid leaching rates showed that there was no significant difference $(P>0.05)$ in percentage of remaining dry weight between the dietary protein levels in trial 2 . 


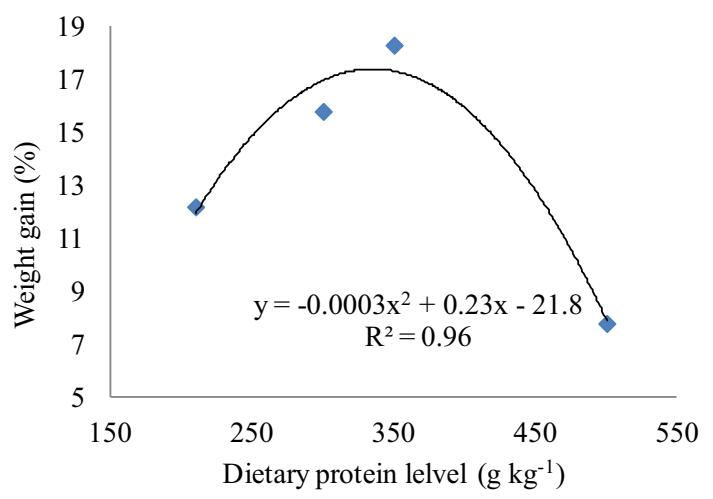

Fig. 2 Relationship between weight gain and dietary protein level of the second trial 2 for C. sandwicensis for 60 days

Table 4 The growth performance of opihi fed various dietary carbohydrate levels for 90 days, specific growth rate (SGR), feed consumption rate $(\% \mathrm{DM} / \mathrm{BW} /$ day $)$

\begin{tabular}{|c|c|c|c|c|}
\hline & \multicolumn{4}{|c|}{ Dietary carbohydrate $\left(\mathrm{g} \mathrm{kg}^{-1}\right)$} \\
\hline & 180 & 270 & 320 & 370 \\
\hline Initial shell length $(\mathrm{cm})$ & $2.80 \pm 0.10^{\mathrm{a}}$ & $2.80 \pm 0.05^{\mathrm{a}}$ & $2.87 \pm 0.29^{\mathrm{a}}$ & $3.11 \pm 0.06^{\mathrm{a}}$ \\
\hline Initial weight $(\mathrm{g})$ & $2.80 \pm 0.51^{\mathrm{a}}$ & $3.56 \pm 0.37^{\mathrm{a}, \mathrm{b}}$ & $3.96 \pm 0.98^{\mathrm{a}, \mathrm{b}}$ & $4.34 \pm 1.20^{\mathrm{b}}$ \\
\hline Weight gain $(\mathrm{g})$ & $0.52 \pm 0.05^{\mathrm{b}}$ & $1.13 \pm 0.15^{\mathrm{a}}$ & $1.06 \pm 0.42^{\mathrm{a}}$ & $0.60 \pm 0.16^{\mathrm{b}}$ \\
\hline SGR $\left(\%\right.$ day $\left.^{-1}\right)$ & $0.20 \pm 0.03^{\mathrm{a}, \mathrm{b}}$ & $0.27 \pm 0.04^{\mathrm{a}}$ & $0.26 \pm 0.07^{\mathrm{a}}$ & $0.15 \pm 0.04^{b}$ \\
\hline Mean feed consumption & $0.58 \pm 0.17^{\mathrm{a}}$ & $0.57 \pm 0.09^{\mathrm{a}}$ & $0.60 \pm 0.27^{\mathrm{a}}$ & $0.45 \pm 0.07^{\mathrm{a}}$ \\
\hline FCR & $0.83 \pm 0.21$ & $0.50 \pm 0.30$ & $0.77 \pm 0.47$ & $1.16 \pm 0.66$ \\
\hline Survival (\%) & 67 & 78 & 78 & 67 \\
\hline
\end{tabular}

a,b Means, within the row, different superscript letters are significant differently $(P<0.05)$

Carbohydrate requirements

Growth performances of opihi that were fed at various carbohydrate levels are shown in Table 4. Statistical analysis by One-way ANOVA showed that there was a significant $(P<0.05)$ difference in weight gain and the specific growth rates of opihi among the diets, then a Tukey test showed that the weight gain of animals on the 180 and $370 \mathrm{~g} \mathrm{~kg}^{-1}$ diets was significantly $(P<0.05)$ lower than animals fed 270 and $320 \mathrm{~g} \mathrm{~kg}^{-1}$ carbohydrate. However, there was no significant difference in specific growth rate of those animals that were fed with diets between the 180 and 270 and $320 \mathrm{~g} \mathrm{~kg}^{-1}$ carbohydrate diets. The mean FCR values show that opihi are efficient converters of feed to body weight. Survival was about $90-100 \%$ for all diets after 2 months, however, the survival rates were $67-78 \%$ after 3 months. The mortality was due handling stress from the second weighing, when we removed them from the colander walls.

Response of opihi in weight gain to dietary carbohydrate levels was then fitted to quadratic models (Fig. 3). It shows that the weight gains of opihi progressively increased and reached their maximum value at a carbohydrate level of about $270 \mathrm{~g} \mathrm{~kg}^{-1}$, which could probably be described as $Y=-0.0012 x^{2}+0.64 x-56.7$ with the correlation value of $R^{2}=0.91$.

Statistical analysis for solid leach rates showed that there was no significant difference $(P>0.05)$ in percentage of remaining dry weight between the two carbohydrate diets. There was about $95.2 \pm 1.90$ and $98.3 \pm 0.20 \%$ remaining dry matter for the dietary carbohydrate levels of 180 and $320 \mathrm{~g} \mathrm{~kg}^{-1}$, respectively, after they were immersed for $12 \mathrm{~h}$. The results suggest that dry matter loss was not a major issue among the different carbohydrate levels. 


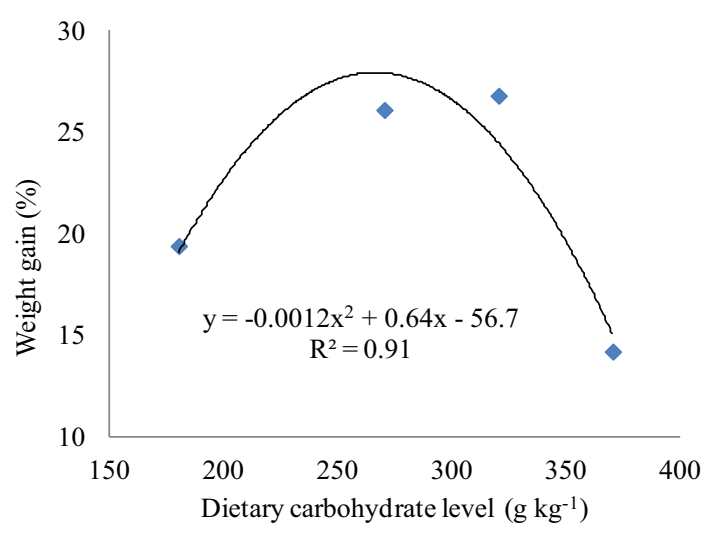

Fig. 3 Relationship between weight gain and dietary carbohydrate level for C. sandwicensis

\section{Discussion}

Determination of optimum dietary protein level which produced the maximum growth of opihi was our first goal in this nutritional study. Our previous study showed that a diet containing fishmeal, soymeal with krill meal, and Porphyra was preferentially consumed and sustained opihi life well (Hua and Ako 2012). This diet was then used as a base diet in the present study and the results support that these dietary protein ingredients would be a practical-formulated feed for the aquaculture of opihi.

The high mortality rate in our first trial raised questions about the statistical strength of our findings about the optimum protein requirement for opihi in that trial. At this stage, it is believed that all the handling and nutritional variables must be taken care of and there should have been only a few mortalities. However, in these longer term experiments $25-50 \%$ total mortalities occurring after animals were removed from the colanders for weighing. Another kind of soft container (Fig. 1) was designed to overcome the colander problems. Animals were removed easily for weighing during the course of experiment by deforming the soft plastic screen. This method improved survival rates significantly to $89-100 \%$, improving the statistical strength of the results of our second trial.

The results of this study showed that the growth of opihi did not correlate to increased dietary protein levels. Statistical analysis by One-way ANOVA showed that there was no significant $(P>0.05)$ difference in weight gain and SGR of opihi among the diets from 270 to $470 \mathrm{~g} \mathrm{~kg}^{-1}$ protein. As stated above, no statistically significant difference in growth rates among the diets may be due to a low survival of animals. Therefore, it is premature to draw any conclusion from the Trial 1 and the data may be use as a preliminary for following trial. Better and significant data were obtained in Trial 2 (Table 3; Fig. 2). The highest weight gain was achieved with the $350 \mathrm{~g} \mathrm{~kg}^{-1}$ protein diet, but there was no significant difference in weight gain with those animals fed with 210 and $300 \mathrm{~g} \mathrm{~kg}^{-1}$ diets. This indicated that opihi could satisfy their needs with a low protein level above $210 \mathrm{~g} \mathrm{~kg}^{-1}$. The trend of the growth rate suggests that when the protein level is too high it may be detrimental to growth. In fact, the results from the $500 \mathrm{~g} \mathrm{~kg}^{-1}$ protein group in the second trial showed poor growth, significantly lower than the other diets, indicating that excess protein is not easily metabolized by opihi.

The second-order polynomial regression model is a way graphical model which allows us to choose an optimal protein level among statistically insignificant differences. In our present study, the $350 \mathrm{~g} \mathrm{~kg}^{-1}$ is the choice by polynomial analysis although it is not statically different from 210 and $300 \mathrm{~g} \mathrm{~kg}^{-1}$ diets (Fig. 2). The pattern of protein requirement for opihi in our study was similar to other studies for abalone species. Mai et al. (1995) also found that the optimal protein level for maximum growth of abalone $H$. discus hannai was about $356 \mathrm{~g} \mathrm{~kg}^{-1}$ dietary protein level, while statistical analysis revealed there was no significant difference in weight gain of abalone that were fed dietary protein from 202 to $353 \mathrm{~g} \mathrm{~kg}^{-1}$ and about $323 \mathrm{~g} \mathrm{~kg}^{-1}$ for $H$. tuberculata (within 202-400 $\mathrm{g} \mathrm{kg}^{-1}$ ). Another study by Sales et al. (2003) stated that the $360 \mathrm{~g} \mathrm{~kg}^{-1}$ protein produced the best growth; however, no statically significant difference occurred between protein levels ranging from 290 to $480 \mathrm{~g} \mathrm{~kg}^{-1}$. 
The specific growth rate of opihi ranged from 0.13 to $0.28 \% \mathrm{BW} /$ day for dietary protein trial 2 . These growth rates are close to the growth rate (approximately $0.2-0.4 \% \mathrm{BW} /$ day) for abalone $H$. discus hannai found by Uki et al. (1985), but lower compared to the growth rate (0.94-1.11\% BW/day) of H. midae reported by Britz (1996). However, may not be valid to compare these values directly between opihi and abalone or even among the abalone species because the apparent requirement may vary due to many different conditions such as difference in diets, experimental species, digestible protein, feed intake, and the management of feeding regimes.

Feed consumption rate seemed to be responsible for growth rate. We have earlier found that feed consumption was correlated with the growth response of opihi (Hua and Ako 2012). Matching the amino acid profile of diets and animal tissue is an important issue, it was believed that it is not sufficient to support optimum growth, because the growth of animals involves many factors including feed intake. In the present study, feed intake tended to be positively related to the growth rate of opihi. The lower feed consumption of animals that were fed $500 \mathrm{~g} \mathrm{~kg}^{-1}$ corresponded to the decrease in the weight gain of animals. Overall, the feed consumption rates were low as compared to our previous study. On the other hand, a lower feed consumption rate in the second trial may be due to a lower carbohydrate level.

The results of our present study demonstrated that various carbohydrate levels in the diet affected growth performances of opihi. Statistical analysis showed that there was a significant $(P<0.05)$ difference in both weight gain and SGR of opihi between the diets (Table 4). There was no significant difference between the weight gain of animal that fed with 270 and $320 \mathrm{~g} \mathrm{~kg}^{-1}$ diets which indicates that the opihi could satisfy their need for carbohydrate with either of the two diets. Polynomial analysis suggests that $270 \mathrm{~g} \mathrm{~kg}^{-1}$ carbohydrate diet would be an optimal level. On the other hand, the cost of feed would probably be higher at the lower carbohydrate levels. Carbohydrate is an inexpensive ingredient. It is noted that non-nutrient ingredients being used as a filter in diet are more expensive than carbohydrate sources. Therefore, the $320 \mathrm{~g} \mathrm{~kg}^{-1}$ carbohydrate could be used as a final level for commercial opihi feed.

A lower carbohydrate level $\left(180 \mathrm{~g} \mathrm{~kg}^{-1}\right)$ may not be sufficient for adequate energy utilization by opihi and part of the energy needed may be catabolized from protein, therefore it may reduce the optimal use of dietary protein for somatic growth. Livingstone and de Zwaan (1983) reported that when insufficient supply of carbohydrate in diet, the animal can be readily synthesized via the catabolism of proteins and lipids. It is unclear why a significantly lower growth rate was seen in animals fed $370 \mathrm{~g} \mathrm{~kg}^{-1}$ carbohydrate. For abalone, literatures have suggested that the abalone would be able to utilize various carbohydrate sources, for example; dextrin (Uki and Watanabe 1989), mixtures of dextrin, wheat flour, sucrose and potato starch (Lee et al. 1998), modified starch (Thongrod et al. 2003), and wheat flour and alginate (Cho et al. 2008; Cho 2010), but provide no quantitative comparisons. It is probably due to high amylase contents in the digestive tract system of abalone (Fleming et al. 1996 and Knauer et al. 1996). Similarly, amylases activity was high in limpet species (Branch 1981). On the other hand, Britz and Hecht (1997) found that increasing the lipid levels of abalone feed decreased the growth rate of abalone. This result indicates a more efficient use of carbohydrates as compared to lipids as an energy source by abalone. This makes sense because abalones mostly eat seaweed and amylase activity is high in abalone (Fleming et al. 1996). Thus, the $320 \mathrm{~g} \mathrm{~kg}^{-1}$ carbohydrate diet would be an optimal level for good growth of opihi in our present study.

In conclusion, this is the first reported study on macronutrient requirements for growth of opihi using an practical artificial diet. The protein level of 350 and $320 \mathrm{~g} \mathrm{~kg}^{-1}$ carbohydrate could be used for generating a commercial feed for opihi if there are no other factors of concern rather than the feed cost.

Acknowledgments This study was supported financially by the Center for Tropical and Subtropical Aquaculture, USA, Grant \#@2009-210 and the Vietnam Education Foundation.

Open Access This article is distributed under the terms of the Creative Commons Attribution 4.0 International License (http:// creativecommons.org/licenses/by/4.0/), which permits unrestricted use, distribution, and reproduction in any medium, provided you give appropriate credit to the original author(s) and the source, provide a link to the Creative Commons license, and indicate if changes were made. 


\section{References}

Alam MdS, Teshima SI, Koshio S, Uyan O, Ishikawa M (2003) Effects of dietary protein and lipid levels on growth and body composition of juvenile Japanese flounder, Paralichthys olivaceus, fed diets containing intact proteins or crystalline amino acids. J Appl Aquac 14:115-131

AOAC international (2000) Official methods of analysis of the association of official analytical chemists, 17th edn. Association of Analytical Communities, Gaithersburg, MD, USA

Branch GM (1981) The biology of limpets: physical factors, energy flow, and ecological interactions. Oceanogr Mar Biol Ann Rev 19:235-380

Britz PJ (1996) Effect of dietary protein level on growth performance of South African abalone. Haliotis midae, fed fishmealbased semi-purified diets. Aquaculture 140:55-61

Britz PJ, Hecht T (1997) Effect of dietary protein and energy level on growth and body composition of South African abalone Haliotis midae. Aquaculture 156:195-210

Cho SH (2010) Effect of fishmeal substitution with various animal and/or plant protein sources in the diet of the abalone Haliotis discus hannai Ino. Aquac Res 41:587-593

Cho SH, Park J, Yoo JH (2008) Effect of casein substitution with fishmeal, soybean meal and crustacean meal in the diet of the abalone Haliotis discus hannai Ino. Aquac Nutr 14:61-66

Coote TA, Hone PW, Van Barneveld RW, Maguire GT (2000) Optimal protein level in a semipurified diet for juvenile greenlip Haliotis laevigatu. Aquac Nutr 6:213-220

Fleming AE, Van Bameveld R, Hone PW (1996) The development of artificial diets for abalone: a review and future directions. Aquaculture 140:5-53

Gomez-Montes L, Garcia-Esquivel Z, D’Abramom LR, Shimada A, Vasquez-Pelaez C, Viana MT (2003) Effect of dietary protein:ratio on intake, growth and metabolism of juvenile green abalone Haliotis fulgens. Aquaculture 220:769-780

Hua TN, Ako H (2012) Enabling studies for aquaculture of the Hawaiian Opihi, the Limpet Cellana. World Aquac Soc 12:40-44

Ju ZY, Forster I, Conquest L, Dominy W, Kuo WC, Horgen FD (2008) Determination of microbial community structures of shrimp floc cultures by biomarkers and analysis of floc amino acid profiles. Aquac Res 39:118-134

Knauer J, Britz PJ, Hetcht T (1996) Comparative growth performance and digestive enzyme activity of juvenile South African abalone, Haliotis midae, fed on diatoms and a practical diet. Aquaculture 140:75-85

Lee SM, Yun SJ, Min KS, Yoo SK (1998) Evaluation of dietary carbohydrate sources for juvenile abalone Haliotis discus hannai. J Aquac 11:133-140

Livingstone DR, de Zwaan A (1983) Carbohydrate metabolism of gastropods. In: Hochachke PW (ed) The mollusca, Vol. 1. Metabolic biochemistry and molecular biomechanics. Academic, New York, pp 177-242

Mai K, Mercer JP, Donlon J (1995) Comparative studies on the nutrition of two species of abalone, Haliotis tuberculata L. and Haliotis discus hannai Ino. IV. Optimum dietary protein level for growth. Aquaculture 136:165-180

National Research Council (1993) Nutrient Requirements of Fish. The National Academy Press, Washington, D.C., pp 345-346

National Research Council (NRC) (1981) Nutrient Requirements of coldwater Fishes, No. 16. The National Academy Press, Washington, D.C

Sales J, Truter PJ, Birtz PJ (2003) Optimum dietary crude protein level for growth in South African abalone (Haliotis midae L.). Aquac Nutr 9:85-89

Satpathy BB, Mukherjee D, Ray AK (2003) effects of dietary and lipid levels on growth, feed conversion and body composition in rohu, Labeo rohita (Hamilton), fingerlings. Aquac Nutr 9:17-24

Taylor B (1997) Protein utilization, hormone treatment and nutrient metabolism as they apply to culture of Haliotis kamtschatkana. $\mathrm{PhD}$ thesis, the University of British Columbia, Canada

Thongrod S, Tamtina M, Chairatb C, Boonyaratpalin M (2003) Lipid to carbohydrate ratio in donkey's ear abalone Haliotis asinina, Linne diets. Aquaculture 225:165-174

Uki N, Watanabe T (1989) Review of nutritional requirements of abalone (Haliotis spp.) and development of more efficient artificial diets. In: Shepherd SA, Tegner MJ, Guzmiin Del SA (eds) Abalone of the World. Fisheries, biology and culture. Fishing News Books, Oxford, pp 504-517

Uki N, Kemuyama A, Watanabe T (1985) Nutritional evaluation of several protein sources in diets for abalone Haliotis discus hannai. Bull Jpn Soc Sci Fish 51:1835-1839 